\title{
Comparing Brazilian And North American Songs About Money
}

\author{
Ruben George Oliven
}

\begin{abstract}
This article compares Brazilian and North American popular music. If focuses on the lyrics of songs composed mainly in the first half of the twentieth century when an intense process of national building was taking place in Brazil and the United States. Several of those compositions became classics. Those songs were and still are very popular because they echoed and continue to echo the social imaginary of both countries. It is for this reason that popular music is so crucial for the understanding of both societies.
\end{abstract}

Keywords: Brazilian Popular Music, North American Popular Music, Samba, Blues, Money

\section{Resumo}

Este artigo compara a música popular brasileira e a norte-americana. Ele enfoca as letras de canções compostas principalmente na primeira metade do século XX, quando um intenso processo de construção de identidades nacionais estava ocorrendo no Brasil e nos Estados Unidos. Várias destas composições se tornaram clássicas. Estas canções eram e ainda são muito populares porque elas ecoaram e continuam a ecoar o imaginário de ambos os países. É por esta razão que a música popular e é tão crucial para a compreensão de ambas sociedades.

Palavras-chave: Música Popular Brasileira, Música Popular Norte-Americana, Samba, Blues, Dinheiro 


\title{
Comparing Brazilian And North American Songs About Money'
}

\author{
Ruben George Oliven
}

\section{I}

Until recently most Brazilian anthropologists concentrated their work within the country's national borders. This was due not only to the lack of funding to carry out research abroad but also to the fact that Brazilian society was (and still is) in the making with many urgent phenomena to be studied (Peirano 1992 \& 2005, Velho 2008). More recently, Brazilian anthropologists have moved further afield, first to neighboring countries where Brazilians have migrated and later to counties such as the United States, Japan and countries of the European Union where other Brazilians are going in growing numbers. There are currently over three million Brazilians living abroad. Brazil is the sixth largest economy of the world and is becoming a major global player. It is therefore natural that it should export not only commodities but also intellectuals. There is a growing number of Brazilian anthropologists doing research abroad. They often study Brazilians who live in other countries and try to understand how they adapt to different cultures. Others aim to understand different societies and to compare them with their own society (Fry 2004).

In the same line of argument developed by Nader when she suggested that anthropologists should "study up", that is, carry out research on the middle and upper levels of the social power structure, as well as the lower (Nader 1972), I would like to suggest that is important that Brazilian anthropologists study other societies. I would argue that it is even more important that they study 'First World' societies. These societies are at the origin of the anthropological enterprise. I am thinking basically about England, France

1 This is an expanded version of my paper presented at the panel Challenges in Brazilian Anthropology: a Global View during the $110^{\text {th }}$ Meetings of the American Anthropological Association. Montreal, Canada, November 20, 2011. The panel was organized by Professor Bela Feldman-Bianco, President of the Brazilian Anthropological Association 
and the United States, the three main centers of irradiation of anthropological thought. They created contemporary anthropological science and are its totemic reference. Their central object of study was originally 'the native', a term usually applied to the members of the colonies or to the first inhabitants of the United States. Very rarely have anthropologists of these countries turned to studying their own society and culture, a task attributed largely to sociologists, historians and political scientists. Anthropologists should study 'overseas', that is beyond the frontiers of their own "culture". Since the members of central countries did not consider themselves natives in this sense, why should they be studied? The picture has been slowly changing, but anthropologists usually do research 'beyond their pale'.

\section{II}

Between August 1993 and January 1995 I was a visiting professor at the Department of Anthropology of the University of California, Berkeley. When I decided to go to the United States, North American scholars who knew my previous work suggested I should study some minority group in the San Francisco Bay Area such as the Brazilians who live there in growing numbers. Since I had just published a book on cultural diversity in Brazil (Oliven, 1996) this would be the 'natural' continuation of what I had been doing at home. Somehow the idea did not appeal to me. I came to the conclusion that this was what one would expect from a Brazilian anthropologist in the United States, i.e., that he or she should study the periphery in the center. As I had already worked on money in the lyrics of Brazilian popular music (Oliven 1999) it occurred to me that this would be a more fascinating subject. When I told North American anthropologists about my plan, they were usually enthusiastic about it but tended to say it was a very broad subject and asked how would I be able to study it in so short a period of time. I was of course also concerned about the feasibility of my project and worried about the time frame. I had no idea about how to start and where to focus my attention.

But from the moment I arrived in the United States (this was the first time I spent a reasonable period of time in that country) I noticed that money was around me all the time and that I was literally so submerged in my research topic that I would have no difficulty finding material. I noticed people were constantly speaking about money and that most things were expressed 
in a monetary idiom.

Money has many implications and is expressed in different dimensions of social life. Abstractly, it is a measuring rod for comparing things, a means by which they are exchanged and stored for holding value (Hart 2000) but what is the value that money "stores"? Part of money's value lies in its pervasive and persuasive capacity as a vehicle of communication to express a variety of values, especially through metaphor and synecdoche. Money is effective not only as a means of exchange but mainly as a means of communication. It helps to mold and organize thought and action. Its effectiveness can be gauged through its persuasiveness. Money is persuasive in use, in talk, in understanding others and in thinking about the self and probably in just thinking alone. If Gudeman (2009) looks at the power of market rhetoric and the way it cascades in theory and on the ground in other economic modes, I consider how money cascades into everyday life in the United States and becomes a vehicle for communicating local values.

Money is an integral part of North American culture and as such it is constitutive of social reality in the United States. It expresses its history, the life cycle, market participation, food, cleanliness, different regions of the country, the future, individualism, religious differences, race relations and fundamental values of citizenship.

Carrying out research on money in the United States I soon realized that it could be looked at as a total social fact, to use Mauss' (1970) concept. Believing that money is a key to understanding North American society, I decided to look at any instance which could bring me clues: scholarly and nonscholarly articles, financial magazines, books on personal finance, proverbs, expressions, banks, investment companies, health insurance, service clubs, compulsive spenders, restaurants, shops. I studied money in relation to love, death, blood, semen, food, God, Catholicism and Protestantism.

Looking at the multifarious aspect of money in the United States I ended up making Americans my "tribe.” I tried to compare attitudes towards money in the United States with those existing in Brazil. Through ethnographic research, I concluded that money is a language and a grammar that is widely used in the United States (Oliven 1998 \& 2009). I also suggested that in North American society money tends to be considered less polluting than in Brazil where it is represented as something potentially dirty perhaps because of the huge social and economic inequalities existing in that country. 
When looking at the significance of money in the United States one is of course reminded of Benjamin Franklin and Ralph Waldo Emerson. Franklin (1706-179o) is quoted at length by Weber in his Protestant Ethic and the Spirit of Capitalism and is frequently hailed as "the first civilized American" and "the apostle of modern times." Among other things, he was a successful inventor and businessman who became also famous for his "proverbs". He published an almanac from 1733 to 1758 that sold about 10,00o copies each year and which "next to the Bible ...might well have been the most frequent reading material in the colonies" (Mieder 1989: 129). Although most of the proverbs of his Poor Richard's Almanack were not invented by him, as he himself made clear, they were associated with his person. "The Way to Wealth," a short article Franklin published in 1758 is an example of the Puritan ethic rendered through 105 proverbs and has become a classic. In it Franklin quotes proverbs such as "God helps them that help themselves," "It is foolish to lay out money in a purchase of repentance," "It is hard for an empty bag to stand upright," "At the working man's house hunger looks in, but dares not enter." In Advice to a Young Tradesman, written in 1748, he says: "Remember, that time is money. ... Remember, that credit is money. ... Remember, that money is of the prolific, generating nature. Money can beget money, and its offspring can beget more, and so on.... Remember this saying, The good paymaster is lord of another man's purse" (Franklin apud Weber 1958: 48-49). Franklin represents the idea of the self-made man, the colonist who does not wait for others to do things for him.

Ralph Waldo Emerson, who lived a century later (1803-1882) is frequently considered "the last puritan" (Santayana 1936, Porte 1979). He can be seen as a champion of the virtues of capitalism stressing the idea of thriftiness, of free enterprise, etc. In his essay "Wealth" published in The Conduct of Life he makes this apology of money: "The world is his, who has money to go over it" (Emerson, 1983: 994). It is interesting that he relates wealth to nature. He argues that "Wealth is in applications of mind to nature; and the art of getting rich consists not in industry, much less in saving, but in a better order, in timeliness, in being at the right spot" (Emerson, 1983: 989). He also stressed that "Men of sense esteem wealth to be the assimilation of nature to themselves, the converting of the sap and juices of the planet to their incarnation and nutriment of their design" (Emerson, 1983: 993). Emerson goes on in his analogy and argues that "It is a doctrine of philosophy, that man is a being 
of degrees; that there is nothing in the world, which is not repeated in his body; his body being a sort of miniature or summary of the world: then that there is nothing in his body, which is not repeated as in a celestial sphere in his mind: then, there is nothing in his brain, which not repeated in a higher sphere, in his moral system. Now these things are so in Nature. All things ascend, and the royal rule of economy is, that it should ascend also, or, whatever we do must always have a higher aim. Thus it is a maxim, that money is another kind of blood. Pecunia alter sanguis: or, the estate of man is only a larger kind of body, and admits of regimen analogous to his bodily circulations" (Emerson, 1983: 1010, emphasis added). In a way, Emerson realized both that money is only good when it circulates and that it is the blood that runs through the veins and arteries of capitalism.

Franklin and Emerson were both born in Boston. Their attitudes towards money represent a more capitalist and north-eastern view of a society which was based on free labor, the idea of the self made man, and providing equal opportunities to all. Analyzing southern ante-bellum folkways regarding money, Ogburn (1964) in an article originally published in 1943, shows that things were different in the Old South where there was not a highly developed money economy largely because farmers were mostly self-sufficient. According to him, although the South changed after the Civil War and money became much more widely used, "some ideas, characteristic of the days of self-sufficing plantation economy, have persisted into the industrial civilization of the twentieth century" (Ogburn 1964: 199). Examples of the survival of attitudes of a moneyless economy are the resistance to the use of money in settling personal differences, the fact that it would be rude to come quickly to business conclusions without any preliminaries, the fact that tipping is less wide-spread a custom than it is in northern cities, the use of expressions such as "this is something money cannot buy," etc. Ogburn argues that these attitudes have a lot to do with an aristocratic society where wealth was based on land not on money, where merchants and businessmen were looked down upon. He draws a comparison with seventeenth and eighteenth century Europe which was not yet a fully monetary economy: "The attitudes of the aristocrats were like the attitudes of a moneyless economy. They high-hatted tradesmen and people who worked for money" (Ogburn 1964: 203).

Sure "money is making an inroad into such personal transactions, but slowly and with resentment" (Ogburn 1964: 203). Ogburn sees these attitudes 
as survivals which sooner or later will disappear: "several of the manners and customs of the South become clearly understood when they are seen as survivals of attitudes of a moneyless society. Money appears first in a limited sphere of transactions in a society. But gradually it penetrates into wider and wider circles of exchanges and relationships. But in doing so, it is opposed. Many of these attitudes of the South after the Civil War are best understood as oppositions to this wider use of money. In the course of time, these survivals will disappear, and the adoption of money will be as complete in the South as elsewhere" (Ogburn 1964: 206).

Some of the attitudes about money mentioned by Ogburn as applying to the Old South can also be noticed in Brazil. Being one of the last countries to abolish slavery (in 1888), Brazil has no tradition of valuing work, especially manual labor. To toil in Portuguese is called "mourejar," something which according to the Portuguese should be left to the moors. A racist expression referring to hard work is "trabalho para negro" (black man's work), a direct reference to slavery. But even after the abolition of slavery and introduction of wage labor in factories, work was never valued because the social order continued to be highly exclusive and hierarchical. Until the nineteen thirties Brazil was an essentially rural society. When industrialization and urbanization started to become more important in the thirties there was a strong reaction against working and the growing monetization of life. At that time one could find the same "resentment against expressing values in money" about which Ogburn (1964: 205) speaks in relation to the Old South. The horror ao batente (hatred of manual work) developed into malandragem (idleness) ${ }^{2}$ which can be seen simultaneously as a survival strategy and a conception of the world through which some segments of the lower classes refused to accept the discipline and monotony associated with the wage-earning world.

\section{IV}

Brazil and United States are of course very different and it is therefore interesting to compare them. They have in common the fact that they are "New World" societies located in the Americas. Both countries were inhabited by

2 A malandro is generally an important male character in sambas, and the word is used in Brazilian society to identify a clever, easy-living trickster (Matta 1991). 
native peoples when the European colonists arrived. They were also slave societies until the second half of the nineteenth century. Whereas in the United States slavery was more concentrated in the South, in Brazil it was spread throughout the whole territory and for three centuries the economy was fully dependent on this mode of production. The first half of the $20^{\text {th }}$ century was a period of great transformations in both countries. They had abolished slavery, received great numbers of immigrants and were going through the processes of urbanization, industrialization, and nation building. The economic crisis of the 1930s affected both countries dramatically. Social life became increasingly monetized and different reactions to this process occurred. World War II was a major event for Brazil and the United States, both of which countries fighting on the same side.

All of this is reflected in popular music, which, I argue provides an opportunity for comparing the two societies. Popular music is a key instance for looking at societies. It reflects day-to-day life, social and political events, changes in morals, cultural values and economic representations. In Brazil and the United States the majority of composers are men and they tend to use music as one of the few public spheres in which they allow themselves to speak more freely about their private feelings. They will sing about their weaknesses, their fear of losses, and their sentiments towards women. Money tends to be a central theme in popular music. It is usually related to other themes like work, social inequalities, gender relations, love (Oliven 2011).

Different scholars (Frith 1996 \& 2007, Middleton 1990 \& 2000, Tagg 2000, Tatit 2002) have pointed to the relation between melody and lyrics in popular music. However, in Brazil and the United States in the first half of the $20^{\text {th }}$ century it was common for one musician to compose the melody and another to write the lyrics. Without denying the relation between melody and lyrics, for the purpose of this article, which is concerned with the messages conveyed through popular music, I will concentrate on the lyrics.

Most of the songs I studied were composed during the first half of the twentieth century, when an intense process of nation building was taking place in both countries. Several of them became classics. I chose to analyze those songs that were and frequently still are very popular because they echoed and continue to echo the social imaginary of both countries.

The negative side of labor is reflected in Brazilian popular music. During the twenties, thirties and forties of the twentieth century samba composers 
used to eulogize malandragem. It developed into a way of life. Government was so worried that Brazilian might be developing a malandro ethic that during the 1937-45 dictatorship the State decided to intervene through its censorship department prohibiting songs which praised malandragem and at the same time giving prizes to those which praised work (Oliven 1984).

The same composers who praised malandragem also depicted money as something ignoble, generally demanded by women who didn't understand that the men they were asking for it had something much more precious to offer them: their love. Of course one can see here a "sour grapes complex": knowing they would never make much money no matter how hard they tried, those men looked down at the vil metal (filthy lucre). On the other hand, in several of the lyrics of these songs one can notice that money is a reality from which one cannot escape in a monetized society. But all of this is seen in a melancholic fashion. And money after all can be very destructive: it sometimes ends love and friendship, and it invites falsehood and treason. As Noel Rosa, one of the great composers of the thirties, put it in Fita Amarela (Yellow Ribbon) a 1933 song co-authored with Vadico (http://www.youtube.com/ watch?v=utUzUVEsgos): "I have no heir/ and I don't have a penny/ I lived my life in debt to everyone/ But I didn't pay them off" ("Não tenho herdeiros/Nem possuo um só vintém/ Eu vivi devendo a todos/Mas não paguei a ninguém").

The first composition to be registered with the name of samba was in 1917. Before that there was practically no music industry and no notion of musical copyright in Brazil. In the United States, the music industry and musical copyright started earlier. In both countries, songs dealing with money also addressed themes like work, love and gender relations.

Samba flourished through the 1920s, matured during the 1930s and by the 1950 it became hegemonic. Together with chorinho and marcha carnavalesca, it formed what became known as MPB (Música Popular Brasileira, or Brazilian Popular Music) (Sandroni 2001, Vianna 1999, McCann 2004).

\section{V}

When analyzing North American popular music of the first half of last century one has to deal with different genres, styles and influences. There is minstrelsy, Tin Pan Alley (the place around $28^{\text {th }}$ street and Broadway in New York where sheet music developed) and of course blues. They all deal with 
money but in different ways. Whereas as in minstrelsy, African-Americans are frequently depicted as not being able to understand the meaning of "time is money" as a central tenet of modern North American life, in Tin Pan Alley songs (Hamm 1979) money is often sung about in a rather frivolous way as a means of attaining luxury (as in "Diamonds are a girl's best friend", a song performed by Marilyn Monroe in Howard Hawks' 1953 film Gentlemen Prefer Blondes: http://www.youtube.com/watch?v=8ZRs_rmYMc). In contrast, in blues, money is central to surviving but difficult to obtain through work (Jones 1963, Levine 1977).

Several songs produced at the end of the nineteenth century and the beginning of the twentieth in the United States deal with money. If Time were Money I'd be a Millionaire (words by Felix F. Feist, music by Ted S. Barron, copyright 1902) is a good example:

A lazy coon a hangin' 'round heard Parson Jenkins say "Dat time was money" And it almost took his breath away He never done a stroke of work He was too big and strong He'd strech out in the boilin' sun And sleep de whole day long

Of course he never had a dollar In his tattered clothes And didn't own a pair of shoes To cover up his toes De only thing he had Was lots of time to pass away

And when he heard Dat time was money Dis is what he did say If time was money I'd be a millionaire I've got time honey An' chunks of it to spare

Oh dere aint no other coon Could get wealth half so soon 
If time was money

I'd be a millionaire

Dis nigger was too lazy

Fo' to raid a chicken roost

Because he'd have

To lift his arm to give

His hand a boost

He nearly starved

To death one day

Fo' certainly because

He didn't have the energy

To move his lazy jaws

Dis coon was never sociable

It tired him to talk

If twenty mules would kick him

All at once he wouldn't walk

'An so a baskin in the sun

Dis nigger laid all day

A grinnin', chucklin' to himself

An' dis am what he'd say

If time was money

I'd be a millionaire

The song was composed by two white musicians at a time when part of the North American population had already been converted to the virtues of productivity and the proper management of time. On the other hand, slavery had been but recently abolished and there were people who were seen as unable to understand this logic. In the song, these are the ex-slaves not yet integrated into new forms of the productive process. The subject of If Time was Money I'd be a Millionaire is seen as a coon, that is, as a person who would today be called African-American, at the same time offensively and disparagingly associated with and synonymous of "a rustic or undignified person" (Webster 1994: 321). Apart from being lazy, he is seen as so naive that he is unable to realize the meaning of the proverb "time is money," a central tenet of capitalist America. Since he does not work and seems to be happy with this situation he has all the time he needs and is led to believe that he is a 
millionaire. The way he is described is full of the prejudices that abounded in the United States at the time the song was composed.

There is an important difference between Brazilian and North American songs as regards race. Brazilian composers of the beginning of the twentieth century were frequently descendants of slaves and had an almost political stance by the fact that they quite consciously rejected work and the ethic associated to it (Oliven 1999). Whereas the subject of If Time was Money I'd be a Millionaire is depicted as being stupid and incapable of understanding what a capitalist ethic means, more or less at the same time Brazilian Black composers were eulogizing idleness and disparaging work. They assumed themselves to be lazy and as having more noble things to do than to think about money. Laziness was taken as a dignified attitude. Actually Macunaima, the main character of one of the formative novels of Brazilian literature, published in 1928, who is the result of a racial mixture (White, Black and Indian), is born lazy and is defined as "a hero without any character." His first words on being born were "boy, do I feel lazy" ("ai que preguiça") (Andrade 1993).

Sloth as an inherited and inevitable trait of personality appears clearly in the samba Caixa Econômica [Savings Bank], recorded in 1933 by Orestes Barbosa and Antônio Nássara (http://www.youtube.com/watch?v=uD_ MEzFroPg \& feature=related):

You want to secure your peace and quiet Watching me kill myself at work Just so you can enjoy yourself

Life is quite comical I am not the Savings Bank Which has interest to collect And what is it you want to buy, huh?

You say that I am a bum

Because I dont go to work I am not a checkbook

For you to get your cash

If you live without worries

Always playing chic

Always in the front row

Pretending I am a teller

And you want to buy what, huh?
Você quer comprar o seu sossego Me vendo morrer num emprego Pra depois então gozar Esta vida é muito cômica Eu não sou Caixa Econômica Que tem juros a ganhar O você quer comprar o que, hem?

Você diz que eu sou moleque porque não vou trabalhar eu não sou livro de cheque Pra você ir descontar Se você vive tranqüila Sempre fazendo chiquê Sempre na primeir fila Me fazendo de guichê E você quer comprar o quê, hem? 
My grandpa died in the struggle

And my father, poor soul

Was exhausted by toil

That's why I was born tired

And, to be fair

I declare to those who work

That my laziness is the way I am

Inherited from my ancestors
Meu avô morreu na luta

E meu pai, pobre coitado

Fatigou-se na labuta

Por isso eu nasci cansado

E pra falar com justiça

Eu declaro aos empregados

Ter em mim essa preguiça

Herança de antepassado

We have here an example in which sloth has become an inherited trait and is transformed into an ethic. The male character, possibly a grandson of a slave and son of a laborer, argues that work is useless for the lower classes.

Laziness is seen as a trait, for which he is not responsible, and which he manifests at the time of his birth.

It is worth noticing that while in a song like When You Ain't Got no Money Well You Needn't Come Round (words by Clarence S. Brewster and music by A.B. Sloane, copyright 1898, presented as "A novel ditty of a love-sick coon") the demanding woman who pronounces the sentence that gives title to the song has the upper hand, in Caixa Econômica, although the female character is the element that drives the plot of the samba, accusing the male narrator of being a bum, he ends up having the upper hand by defending himself forcefully. He does this at two levels. Besides arguing that laboring is useless for the lower classes, his second level of defense is a counter-attack, expressed in the accusation that the woman is an insatiable consumer and that she has a predator-like character since she wants to obtain stability by entering the world of order, represented by a salaried job. The man also rejects any association between himself and anything that reminds him of money.

\section{VI}

In these songs love is usually seen as morally superior to money. An example of the sublime nature of love can be found in the North American song Something that money can't buy (words by Charles Horwitz, music by Frederick V. Bowers, copyright 1900):

Gold has its power

Sages will say 
Riches in life

Hold a wonderful sway

But there's a power

Hails from above

Greater and better

Power of love

There strolls a noble

Money and land

Lives in a mansion

Costly and grand

Still he's unhappy

No one knows why

Love is the power

Money can't buy

Love of a mother

For her darling child

Love for a son

Tho' he's wayward and wild

Love that brings joy

And a tear to the eye

This love is something

That money can't buy

There sits a maiden weary at heart

sighing for one who had

Vow'd ne'er to part

Two lives were happy

Till one sad day

There came a message

He'd pass'd away

Still she is constant

Never will wed

True to the one who lies buried

'tis said

Rich men to win her 
One and all try

Her love is something money can't buy

Love of a soldier

His flag to defend

Loving Old Glory

He fights to the end

True to these colors and for it he'd die

This love is something that money can't buy

The song is an unswerving assertion of the superiority of love in relation to money.

Sinhô, a black Brazilian composer of the beginning of the twentieth century known as the "King of Samba" found out that "samba could bring in money, prestige, and even good polemics - three things that pleased him greatly... His favorite themes were the chronicling of daily and love stories with special emphasis on matters of money and women, his greatest preoccupations in real life" (Severiano 1988). In 1918, he wrote Quem são Eles [Who are they], his first Carnival success. One of the verses states:

No need to ask
I'll give it to you
I don't have any money
But I can steal some

The theme of money appears incidentally in this song, in the middle of other themes, as if it were something of lesser importance. The fellow has no money and to get it, he will not avail himself of work, considered unworthy, but of theft. As he presents himself as uninterested in material preoccupations, it becomes implicit that it is a woman who is asking him for money and that she is not indifferent to financial matters.

O Pé do Anjo [The Angel's Foot], in the carnival march idiom, recorded in 1920 (http://www.youtube.com/watch?v=JboqkLrrI8U), was one of Sinhô's greatest hits. In it the "King of Samba" sings of women and money in one of the verses:

The woman and the hen

Are two selfish animals

The chicken for corn

And the woman for money
A mulher e a galinha

São dois bichos interesseiros

A galinha pelo milho

E a mulher pelo dinheiro 
The woman is compared to the chicken which is always pecking, and she is regarded as a selfish, money-consuming creature. The idea is that while men stand above material interests, women are constantly bringing up such an ignoble topic as money. Xisto Bahia, one of the precursors of Brazilian Popular Music, concluded, Isto ébom [This is good], a march written in 1880 (http://www.youtube.com.watch?v=iUqorvESjQI) for a music hall performance by saying, "Whoever wants goods things/ Should not love money."

In the march Amor sem dinheiro [Love without money], one of the hits of the 1926 Carnival, Sinhô discusses the relationship between money and love, showing the impossibility of fully loving without adequate financial conditions:

$\begin{array}{ll}\begin{array}{l}\text { Love, love } \\ \text { Love without money, honey } \\ \text { Has no value }\end{array} & \begin{array}{l}\text { Amor, amor } \\ \text { Amor, sem dinheiro, amor } \\ \text { Não tem valor }\end{array} \\ \begin{array}{l}\text { Love without money } \\ \text { Is a flash in the pan } \\ \text { It is a house without an owner } \\ \text { Where the scum lives }\end{array} & \begin{array}{l}\text { Amor sem dinheiro } \\ \text { É fogo de palha }\end{array} \\ \text { Eove, love, etc. } & \begin{array}{l}\text { Em que mora a canalha } \\ \text { Love without money }\end{array} \\ \begin{array}{l}\text { Is a withered flower } \\ \text { Verses that don't rhyme } \\ \text { Take me and I'll go }\end{array} & \text { Amor, amor, etc. } \\ & \text { Amor sem dinheiro } \\ \text { Love, love, etc. } & \begin{array}{l}\text { Eflor que murchou } \\ \text { São quadras sem rima }\end{array} \\ \text { Love without money } & \text { Me leva que eu vou } \\ \text { Is sugarcane without juice } & \\ \text { A frog in the pond } & \text { Amor, amor, etc. } \\ \text { Singing wearily } & \end{array}$

The song's argument is clear: love needs a financial base without which it is merely a "flash in the pan." It is interesting, however, that the same Sinhô released in 1928 another samba, Que vale a Nota sem o Carinho da Mulher [What is money good for without the caresses of a woman], which goes in the opposite direction. In the first verse, he proclaims the supremacy of love over money: 
Love! Love!

It is not for those who want it

What is dough worth, my honey

Without the pure tender touch of a woman?

(when she wants it)
Amor! Amor!

Não é pra quem quer

De que vale a nota, meu bem

Sem o puro carinho de uma mulher (quando ela quer)

The title condenses the meaning of the song. It affirms the value of love over money, which is of no value without the caresses of a woman. There is a pervading tension in songs of this period that deal with money. On the one hand, everyone knows that in an increasingly monetized society such as Brazil's in that period, money is needed to fulfill one's wishes. But since it is difficult for poor men to earn much through manual labor, they express their sour grapes by claiming that affection is much more important than wealth. These compositions from the early twentieth century are marked by the copresence of awareness that money is increasingly important, and the belief that affective and magical solutions can minimize scarcity. This contradiction appears, at times, in the songs of a single composer, such as Sinhô.

\section{VII}

Gender is part of the picture of Brazilian and North American songs about money composed at the end of the nineteenth and the beginning of the twentieth centuries. Although most of the composers were male, they frequently constructed a feminine narrator. Women can either be sublime in the love they provide or very mean because they ask for money. In the compositions of that time, money is more and more associated with the figure of the woman (Oliven 1988). We enter here in the realm of expectations and complaints between men and women - themes that are abundant in the compositions at that time. The songs show both the masculine point of view as well as the feminine one (shown through the male imagination). As love relationships are made up of expectations, we always confront a tension between what is expected or demanded of the opposite sex and what is obtained from it. Also, always present is what was done to attend to the other's expectations and the gratitude or ingratitude generated by the action. Popular music at that time reflects this world of expectations and complaints in a register that is at times humorous and at other times resentful.

In North American songs, women also appear as making 
constant demands of money. In Money Blues (http://www.youtube.com/ watch? $=s V v F a B 38 g c s)$, composed by D. Leader and H. Ellers and recorded by Bessie Smith, 1926 we have a direct reference to money:

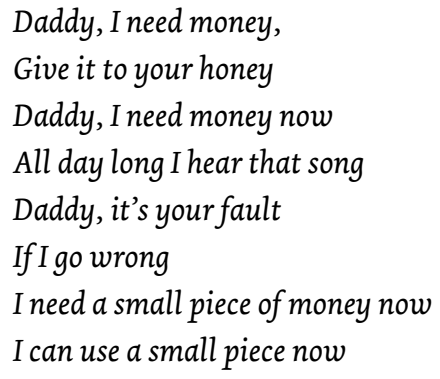

Several other songs sung by Bessie Smith speak directly about money or the lack of it: Hard Times Blues, Homeless Blues, Poor Man Blues, Washwoman blues, Nobody knows you when you are down and out.

Why Don't You Do Right (Get Me Some Money, Too!) (www.youtube.com/ watch?v=Z_lnE_L_E8M), copyright 1941, by Joe McCoy, an African American Delta blues musician and songwriter born in Mississippi also depicts a woman demanding money from her man. She complains about her partner's financial insolvency:

\author{
You had plenty money \\ Nineteen twenty two \\ You let other people \\ Make a fool of you \\ Why don't you do right \\ Like some other men do? \\ Get out of here and \\ Get me some money too \\ Yo' sittin' down \\ Wond'ring \\ What it's \\ All about \\ If you ain't \\ Got no money \\ They will \\ Put you out
}


Why don't you do right ...

If you had prepared twenty years ago

You wouldn't be

Wandering now

From do' to do'

Why don't you do right ...

The song deals with themes that were common in blues following the Great Depression. The woman complains that her partner is broke because he spent his money on other women who no longer have any interest in him now that he is poor. Her refrain is that he should 'do right' like other men do, insisting that he must earn a living in order to support her.

But when the man is the provider power relations between sexes based on money crop up as can be seen in Paying the Cost to be the Boss (www.youtube. com/watch?v=oMuBIOmGFHM), a song of 1968 with words and music by B.B. King, an African-American blues guitarist and singer-songwriter, born in Mississippi:

You act like you

Don't wanna listen

When I'm talking to you

You think you ought to do, baby

Anything you want to do

You must be crazy, baby

You just got to be out of your mind

As long as I'm paying the bills, woman

I'm paying the cost

To be the boss

I'll drink if I want to

And play a little poker, too

Don't you say nothing to me

As long as I'm taking care of you

As long as I'm working, baby

And paying all the bills 
I don't want no mouth from you

About the way I'm supposed to live

You must be crazy, woman

You just gotta be out of your mind

Now that you've got me

You act like

You're ashamed

You don't act like any woman

You're just using my name

I tell you I'm gonna handle all the money

And I don't want no back talk

'Cause if you don't like

The way I'm doing

Just pick up your things and walk

You gotta be crazy, baby

You must be out of your mind

As long as I'm footing the bills

I'm paying to the cost

To be the boss

If we look at Brazilian songs we notice that women are also not satisfied with their men. In É o que ele quer [That's what he wants], a composition by Oswaldo Santiago and Paulo Barbosa in 1938, we find the image supposedly held by the woman of a male dream:

Good house and good clothes

And home cooked meals

That's what he wants

That's what he wants

A life of fun

With the woman's money

That's what he wants

That's what he wants

This is too much
Boa casa e boa roupa

E comida de mulher

É oque ele quer

É oque ele quer

Uma vida de orgia

Com o dinheiro da mulher

É o que ele quer

É oque ele quer

Isso é demais 
It cannot be

He who does not work

Should not live

This young man even wants

Me to chew

So he can eat
Não pode ser

Quem nao trabalha

Não deve viver

Esse rapaz chega querer

Que eu mastigue

Pra ele comer

In Brazilian popular music of the first half of last century women were more and more insistent on reminding men that they should work and earn money, as in the 1942 samba Vai Trabalhar [Go to work] (http://www.carmenqueiroz.com. br/b/b.php/a/r/ip/59) by Cyro de Souza:

\section{I don't like this \\ It doesn't look good \\ I am doing my thing \\ at the wash basin \\ To earn money}

And you in the samba

All day long, oh

All day long, oh

All day long, oh

You understand

And pretend that you don't

That everything depends on good will

For our lives to straighten up

You must cooperate

You are strong and you can help

Look for a job

Leave the samba

And go to work

\begin{abstract}
Isso nao me convém
E nao fica bem

Eu no lesco-lesco

na beira do tanque
\end{abstract}

Pra ganhar dinheiro

E você no samba

$O$ dia inteiro, ai

$O$ dia inteiro, ai

$O$ dia inteiro, ai

Você compreende

E faz que nao entende

Que tudo depende de boa vontade

Pra nossa vida endireitar

Voce deve cooperar

É forte e pode ajudar

Procure emprego

Deixe o samba

E vai trabalhar

Although composed by a man, the narrator is a woman (who takes in laundry to make money) who is complaining about her man who instead of working dances the samba and is kept by her work. But live by working is difficult, as shown in Vida Apertada [A tight life], a samba from 1940 (http://www.youtube. com/watch?v=k-yruButp-A) by the same composer: 
My God, what a hard life

I work but I have nothing

I live in total martyrdom

Life has no enchantment

For one who suffers so much

This way, I'll end up in a mess

Being poor is not a defect

But unhappiness

I don't even have the right

To enjoy my youth

I leave work late

And get home half-dead

Because I have to endure work on the docks

Every day at the harbor
Meu Deus, que vida apertada

Trabalho, não tenho nada

Vivo num martírio sem igual

A vida não tem encanto

Para quem padece tanto

Desse jeito eu acabo mal

Ser pobre não é defeito

Mas é infelicidade

Nem sequer tenho direito

De gozar a mocidade

Saio tarde do trabalho

Chego em casa semi-morto

Pois enfrento uma estiva

Todo o dia lá no cais do porto

The subject of the composition is killing himself as a stevedore and he realizes that besides not earning very much, he doesn't even have the right to enjoy his youth. A similar theme is in Será possivel? [Is this possible?], by Rubens Campos and Henricão from 1941:

Ai, ai, ai, I am already tired
of trying to control myself
My money was never enough
for anything
It's for eating badly and dressing
to pay for the shack and not making it
I am already disillusioned
because this way
I know that I will be finished
I worked all year
to see if I could straighten out
I saved so much
I even cooked without any grease at home
To travel by trolley I waited for the second
class street car

Ai, ai, ai...ja estou cansado de querer me controlar O meu dinheiro nunca deu pra outra coisa É pra comer mal e vestir pagar o barraco e olhe lá Eu ja ando desanimado que desse jeito eu sei que vou me acabar

Trabalhei o ano inteiro pra ver se endireitva Eu fiz tanta economia Até em casa cozinhava sem gordura Pra viajar de bonde esperava o caradura

A recurring theme during that time focuses on the woman's interest in money and the pressure that she exerts on her man for him to obtain it. The invariable answer by the man is that he is going to get some, but this is 
secondary when compared to the affection that he has to offer her. This is perfectly clear in Dinheiro não Há [There is no money], by Benedito Lacerda and H. Alvarenga in 1932 recorded in 1932 (http://www.youtube.com/watch?v=nBo_ tvcAxeo):

\begin{tabular}{|c|c|}
\hline There she comes crying & Lá vem ela chorando \\
\hline What does she want? & O que ela quer? \\
\hline Not a beating & Pancada nãoé \\
\hline I know & Já sei \\
\hline Fun-loving woman & Mulher da orgia \\
\hline When she begins to cry & Quando começa a chorar \\
\hline She wants money & Quer dinheiro \\
\hline There is no money & Dinheiro não há \\
\hline There is none & Não há \\
\hline Love I have too much & Carinho eu tenho demais \\
\hline To sell and to give & Para vender e dar \\
\hline Beatings will also not be lacking & Pancada não há de faltar \\
\hline Money, not that & Dinheiro, isto não \\
\hline I don't give that to women & Eu não dou à mulher \\
\hline But I promise on earth, & Mas prometo na terra \\
\hline The sky and the stars & O céu e as estrelas \\
\hline If she wants them & Se ela quiser \\
\hline But there is not money & Mas dinheiro não há \\
\hline
\end{tabular}

The woman (fun-loving in this case) is seen as always wanting money The song affirms the scarcity of cash and the abundance of love that can even take the form of physical aggression as in several other contemporary songs.

In these songs women are complaining to their men that they are not performing what is considered their basic role in society: to be providers. The best the men can say is that they are unable to provide money but that they have plenty of love to offer.

One of the few "solutions" at hand for those men was to dream that they had suddenly become rich like in If I had a Million Dollars (http://www.youtube.com/watch?v=oyJ4MD_1W_E) (words by Johnny Mercer, music by Matt Mallneck, copyright 1934):

Castles with their thrones 
Ships up on the sea

Gold and precious stones

All belong to me

Foolish though it seems

Ev'ry word is true

Though they're only

Mine in dreams

My dreams belong to you

If I had a million dollars

I know just what I would do

I'd tie a string around the world

And bring all of it to you

Those little things you pray for

Whatever they may be

I'd have enough to pay for them all.

If I spent the million dollars

I know I would never care

Because as long as you were mine

I'd still be a millionaire

That's why I'm always dreaming

Dreaming of what I'd do

If I had a million dollars and you.

In Acertei no Milhar [I hit the jackpot], a samba written by Wilson Batista and Geraldo Pereira, recorded in 1940 (http://www.youtube.com/ watch?v=2eOpqjyjX6I), hitting the jackpot represents the ideal of salvation:

Etelvina, my darling!

What is the matter, Jorginho?

I hit the jackpot

I won 500 bucks

I am no longer going to work

Give all my old clothes to the poor

We can destroy all the furniture

This instant

Hand them over to me

Etelvina

We'll have another honeymoon

You'll be a fine lady
Etelvina, minha filha!

Que há, Jorginho?

Acertei no milhar

Ganhei 500 contos

Não vou mais trabalhar

E me de toda roupa velha aos pobres

E a mobilia podemos quebrar

Isso é prajá

Passe praca

Etelvina

Vai ter outra lua de mel

Você vai ser madame 
You'll live in a big hotel

Vai morar num grande hotel

And I will buy a name somewhere or another Eu vou comprar um nome não sei onde

of a Marquis, Lord Jorge Veiga, of a Viscount

A French teacher, mon amour

I'm gonna change your name

To Madame Pompadour

At last now I am happy

I will travel all over Europe to Paris

-And our children, huh?

-Oh, what the Hell!

-I will put them in a boarding school

Call Mané from the grocery shop

Because I don't want

To be in debt to anybody any longer

I'll buy a blue airplane

To travel around South America

But then, suddenly, all of a sudden

Etelvina called me

It's time to work

Etelvina woke me up

It was all a dream, folks
De marquês, Dom Jorge de Veiga,

de Visconde

Um professor de francês, mon amour

Eu vou trocar seu nome

Para Madame Pompadour

Até que enfim agora eu sou feliz

Vou percorrer Europa toda até Paris

- E os nossos filhos, hein?

- Oh, que inferno!

- Eu vou pô-los num colégio interno

Me telefone pro Mané do armazém

Porque não quero ficar

Devendo nada a ninguém

Eu vou comprar um avião azul

Pra percorrer a América do Sul

Aí de repente, mas de repente

Etelvina me chamou

Esta na hora do batente

Etelvina me acordou

Foi um sonho, minha gente

The background of the song is prontidão (pennilessness) and the difficulties that stem from it such as having to work, debts to pay, and so forth. The way out is in the world of dreams. The narrator dreams that he has won a large amount of money from gambling and he quickly declares that he is no longer going to work. A world of fantasies follows such as a new honeymoon, international trips, living in a hotel, children in a boarding school, brand new furniture, paying off debts, and so forth. From being a mere worker, the narrator climbs up the social ladder to become not a member of the bourgeoisie, but a nobleman. All this will be brought about by money. But a lot of money is only possible by hitting the jackpot, and, as he discloses in the end, it was all but a dream. The woman is the object of this fantasy: it is to her that the dream will be told, it is she who will become a "lady", it is also she who will call him back to reality - that is, to work. The "aversion to drudging work", which characterizes the malandro, runs through the entire composition. 
A similar theme appears in Saquinho de Papel [Little paper bag] (http://www. youtube.com/watch?v=MKgGRnpSqqs) by Cyro Monteiro and Lilian Bastos:

If life were like we want it

Oh how good it would be

How good it would be

We would only sing

Night and day

Nobody would work

They would just spend

In a big house we would live

We would eat, sleep and dream

And happiness would remain with us

And every night in the yard

There would be samba with drums

Whoever has a guitar would sing

Who was good at singing, would sing

And happiness would remain with us

And every end of the month

A little bag of money in the yard

So that we could pay what we spent

Pay for food, pay for drink

Pay for the clothes that we wore

And the rent

This money would all come from heaven

Oh, what a nice dream

How great it is to dream like this

Oh, if I could only never wake up

from this dream
Se a vida fosse como a gente queria

Ah que bom seria

Que bom seria

A gente só cantava

De noite e de dia

Ninguém trabalhava

Só gastava

Numa casa grande a gente morava

A gente comia, dormia e sonhava

$E$ a felicidade com a gente ficava

$E$ todas a noites no terreiro

Tinha samba firme de pandeiro

Quem tinha viola cantava

Quem era de cantar, cantava

E a felicidade com a gente ficava

E todo o fim de mês

Um saquinho de dinheiro no terreiro

Pra gente pagar o que gastou

Pagar comida, pagar bebida

Pagar a roupa que vestiu

E o aluguel

Esse dinheirinho viria todinho la do céu

Ah, que sonho bom

Comoébom sonhar

Ah, se eu pudesse jamais

desse sonho acordar

Big Rock Candy Mountain (Harry Kirby McClintock) (http://www.youtube. com/watch?v=ovKk_kPmAk4) was composed in 1928, the same year of Sinhô's Que vale a Nota sem o Carinho da Mulher [What is dough worth without a Woman's Tenderness] and sings about a "land that's fair and bright,/ The handouts grow on bushes/ And you sleep all night." Not only do handouts grow on bushes, but it is a land "Where you sleep all day,/ Where they hung the jerk/ That 
invented work." It is interesting that at no moment is the word money pronounced in the song.

Shortly after the song was composed the crash of Wall Street occurred. The Great Depression made itself felt in music. Money, or rather the lack of it, appears in several songs of the period. The classic Brother, Can You Spare a Dime? (http://www.youtube.com/watch?v=4F4yToKAMyo) (words by E.Y. Harburg, music by Jay Gorney, copyright 1932) is an example. The expression "Brother can you spare a dime?" is not only a direct reference to money but also an admittance that money is difficult to get by in a land that made the promise that you could get rich if you worked. The Gold Diggers' Song (We're in Money) (http://www.youtube.com/watch?v=UJOjTNuuEVw) (words by Al Dubin, music by Harry Warren, copyright 1933 renewed) expresses the hope the bleak times of the Depression are over and also makes direct reference to money already in its subtitle:

\section{Gone are my blues \\ And gone are my tears \\ I've got good news \\ To shout in your ears}

The silver dollar

Has returned to the fold

With silver you

Can turn your dreams to gold

We're in the money

We've got lot of

What it takes

To get along!

We're in the money The skies are sunny Old man depression You are through You done us wrong!

We never see a headline 'bout a breadline today And when we see the landlord 
We can look that

Guy right in the eye

We're in the money

Come on, my honey

Let's spend it

Lend it

Send it rolling along!

The song ends with the message that money has to circulate in order to breed more, hence it has to be spent or lent.

With Plenty of Money and You (Gold Diggers' Lullaby) (http://www.youtube. com/watch?v=Xiz8OgDQgoE) written for the musical Gold Diggers of 1937 also deals with the question of love and money:

Verse:

I have never envied folks with money,

Millionaires don't get along so well;

I have you, but haven't any money,

Still the combination would be swell;

Chours:

Oh, baby, what I couldn't do-00-00,

With plenty of money and you-00-00;

In spite of the worry that money brings,

Just a little "filthy lucre" buys a lot of things;

And I could take you to places you'd like to go,

But outside of that, I've no use for dough;

It's the root of all evil,

of strife and upheaval;

But I'm certain, honey,

That life could be sunny,

With plenty of money and you.

The song makes direct reference to the New Testament idea of money as "filthy lucre." But it does it in a clever way. It does not deny that money is the "root of all evil" ( 1 Timothy, 6:10) but all the narrator wants is to have plenty of it in order to enjoy the affection of the woman he loves. Other than that, he thinks, money has no use. Which means that love can cancel out the negative aspects associated with money. 
The dilemma of love versus money is a constant during this period. Like the decade of the twenties, many songs during the decade of the thirties emphasize that love is much more important than money and that the latter does not bring happiness. It is better to be poor and happy rather than rich and miserable. This is what one finds in the 1940 samba by Benedito Lacerda and Herivelto Martins, E o vento levou [Gone with the wind] (http://www. youtube.com/watch?v=CgQHoBJlmM4), the same title of the famous North American film:

\begin{tabular}{|c|c|}
\hline Where is the money? & Onde está o dinheiro? \\
\hline Gone with the wind... & O vento levou... \\
\hline Your jewelry, your home? & Suas jóias, sua casa? \\
\hline Gone with the wind... & O vento levou... \\
\hline And the woman that you had? & E a mulher que você tinha? \\
\hline She flew the coop... & Bateu asas e voou... \\
\hline Everything that I possessed & Tudo que eu possuia \\
\hline Gone with the wind... & O vento levou... \\
\hline I have been rich, I have been noble & Já fui rico, já fui nobre \\
\hline I have been elegant and a big spender & Fui grã-fino e gastador \\
\hline Everyone greeted me this way: & Todos me cumprimentavam assim: \\
\hline Hello, Doctor & Olá, seu doutor \\
\hline Even this nickname is gone with the wind... & Até esse apelido o ventou levou... \\
\hline Where is... & Onde está (...) \\
\hline He who has been a millionaire & Quem já foi um milionário \\
\hline He who has had and does not have today & Quem já teve, hoje não tem \\
\hline Wherever I go & Onde eu passo \\
\hline Everyone shouts this way: & Todos gritam assim: \\
\hline Hello, Mr. Nobody & Olá, João-ninguém \\
\hline Some day the wind storm & Qualquer dia a ventania \\
\hline Will take me also & Me leva também \\
\hline Where is... & Onde está (...) \\
\hline
\end{tabular}

The song shows how much a rich man is pampered, and how he ends up being abandoned when he loses his fortune. To be rich always involves the risk of loss and suffering.

But the composers become more aware of the importance of money to 
build a positive emotional relation. Romance Without Finance (http://www.youtube.com/watch?v=_BnFRd11sMk) (Charlie Parker, 1944) speaks precisely about this question:

Romance without finance is nuisance

Baby, you know I need me some gold

Romance without finance just don't make sense

Mama, mama, please give up that gold

You so great and you so fine

You ain't got no money you can't be mine

It ain't no joke to be stone broke

Baby, you know I'd lie when I say

Romance without finance is a nuisance

Please please baby give me some gold

Romance without finance is nuisance

Oh baby, I must have me some gold

Romance without finance just don't make sense

Oh baby, mama, mama, give up that gold

You so great and you so fine

You ain't got no money you can't be mine

It ain't no joke to be stone broke

Baby, you know I'd lie when I say

Romance without finance is a nuisance

Here we have a clear message that it is impossible to develop a satisfactory love relation if an adequate financial basis is not present. In If You've got the Money, I've got the Time (http://www.youtube.com/watch?v=f2xofMszj58) (Lefty Frizzell and Jim Beck, 1950) this idea is developed in an even more direct way: "If you got the money, I've got the time/ But if you run short of money I'll run short of time/ Cause you with no more money honey I've no more time."

Busted (Ray Charles) (http://www.youtube.com/watch?v=VLWoiC-3b6o), a song composed in 1963 deals with material reality:

My bills are all due and the baby needs shoes and I'm busted

Cotton is down to a quarter a pound, but I'm busted

I got a cow that won't dry and a hen that won't lay

A big stack of bills that gets bigger each day

The county's gonna haul my belongings away cause I'm busted. 
I went to my brother to ask for a loan cause I was busted

I hate to beg like a dog with his bone, but I'm busted

My brother said there ain't a thing I can do,

My wife and my kids are all down with the flu,

And I was just thinking about calling on you 'cause I'm busted.

Well, I am no thief, but a man can go wrong when he's busted

The food that we canned last summer is gone and I'm busted

The fields are all bare and the cotton won't grow,

Me and my family got to pack up and go,

But I'll make a living, just where I don't know cause I'm busted

I'm broke, no bread, I mean like nothing

Although the song makes no bones about the ordeal the narrator is going through, it does not mention the word money. A very similar situation can be found in Pode guardar as Panelas [You can put away the pans] (http://www.youtube. com/watch?v=zoZqHMzfsl8), a 1979 samba by Paulinho da Viola:

You know that the tide

Is a piece of cake

And those who sleep without a cap

Know what it is all about

I know that my heart aches

When I talk the way I did

To say that the worst has happened

You can put away the pans

Because today the money fell short

(you know that the tide)

I struggled a lot

Asking for loans but nobody lent me

I went over to Mr. Malaquias

To buy on credit but he didn't let me

My salary, tight, poor thing, it's funny

I has disappeared

\section{Iresorted to the horses, I bet on the favorite Fui apelar pro}

But it didn't work out

(you know that the tide)

You know that the tide ... etc.

To fill our pans, woman

I don't know how
Você sabe que a maré

Não está moleza não

E quem não fica dormindo de touca

Já sabe da situação

Eu sei que dói no coração

Falar do jeito que falei

Dizer que o pior aconteceu

Pode guardar as panelas

Que hoje o dinheiro não deu

(você sabe que a maré)

Dei pinote adoidado

Pedindo empréstimo e ninguém emprestou

Fui no seu Malaquias

Querendo fiado mas ele negou

Meu ordenado, apertado, coitado, engraçado

Desapareceu

Mas ele não deu

(você sabe que a maré)

Você sabe que a maré... etc.

Para encher nossa panela, comadre

Eu não sei como vai ser 
I have run around everywhere

I did what I could do

Hoping for a miracle

That would work things out

My faith is wavering

And I don't want to be disappointed again

(you know about the tide)
Ja corri pra todo lado

Fiz aquilo que deu pra fazer

Esperar por um milagre

Pra ver se resolve a situação

Minha féjá balançou

Eu não quero sofrer outra decepção

(você sabe que a maré)

The song, which represents a complete change about the question of money, expresses the loss of past illusions. The chorus repeats all the time, like a background painting, the economic situation of the popular classes and their related difficulties. In spite of recognizing that this may hurt one's feelings, the narrator prefers to be honest and direct. The impact is strong, for money is associated directly with food. Contrary to sambas from other times, in which the word money was frequently avoided, here it is cited explicitly. The narrator is a salaried worker whose earnings do not cover the month's expenditure. Therefore, he is obliged to try some alternative forms of getting money. But the methods that he utilized in other times (borrowing, buying on credit, gambling) no longer help and he no longer believes in miracles, hence his profound disillusionment. The title of the samba itself, You can put away the pans, suggests a retreat, the absence of any solution on the horizon.

\section{VIII}

This article has argued that popular music is a key instance for comparing societies. It expresses the changes that take place in different societies and allows us to understand how they are interpreted and represented by its members. It is interesting to compare the social imaginaries of popular music of Brazil and the United States because, although they are very different countries, they have a lot in common. The lyrics of popular songs represent an important social space for understanding the transformations through which those two societies went through during the twentieth century, in particular nation building, urbanization and industrialization. During that period, cities were the stage for a rearrangement of work relations, the dissemination of wage labor, a redefinition of gender roles, and new forms of family organization. Relations became gradually more monetized and hence money or the lack thereof became 
a crucial reality of daily life. These changing realities are richly expressed through the lyrics of popular music.

There is a parallelism in the Brazilian and the North American songs analyzed in this article. The songs of the nineteen twenties represent a period in which people could still dream of surviving without working and of a society in which idleness and love could be imagined possible and preferable to salaried work and the need for money. The songs of the second half of last century, on the other hand, are much more 'realistic.' The narrators are poor, mainly of African descendent in both cases, and they speak about the difficulty of earning money through wage work. Contrary to the lyrics of the 1920s, in which the word money was frequently avoided, here it is cited explicitly. The songs witness the end of an era. The period begins with the composers affirming the unimportance of money through wage labor and the dream of obtaining it magically, and ends with the recognition of its importance and the enormous difficulty of obtaining it. Money becomes more and more part of everyday reality. As the title of one of the songs of the 1966 Broadway musical Cabaret asserts: "Money makes the world go round" (http://www.youtube. com/watch?v=rkRIbUT6u>Q).

\section{Acknowledgment}

The author thanks Professor Peter Fry, editor of Vibrant, and the anonymous reviewers of this article for their very useful comments and suggestions.

\section{References}

ANDRADE, Mário de. 1993 (1 $1^{\text {st }}$ edition: 1928). Macunaíma. O Herói sem Nenhum Caráter. 1993. Belo Horizonte: Villarica.

FRITH, Simon. 1996. “Songs as Texts”. In: Performing Rites: on the value of popular music. Cambridge, MA: Harvard University Press, pp. 158-182.

FRITH, Simon. 2007. "Why do songs have words?". In: Taking Popular Music Seriously. Aldershot: Ashgate, pp. 209-238.

FRY, Peter. 2004. “Internacionalização da Disciplina”. In: W. Trajano Filho, \& G. L. Ribeiro, (eds). O Campo da Antropologia no Brasil. Rio de Janeiro: Contra Capa, pp. 227-248.

GUDEMAN, Stephen. 2009. “The Persuasions of Economics”. In: S. Gudeman, 
(ed). Economic Persuasions (volume 3 of Studies in Rhetoric and Culture Series). New York and Oxford: Berghahn, pp. 62-80.

HAMM, Charles Hamm. 1979. "It's Only a Paper Moon. Or, the Golden Years of Tin Pan Alley”. In: Yesterdays. Popular Song In America. New York: W.W. Norton \& Company, pp. 326-39o.

HART, Keith. 2000. The Memory Bank. Money in an Unequal World. London: Profile. JONES, LeRoi (Amiri Baraka). 1963. Blues People. Negro Music in White America. New York: William Morrow and Company.

LEVINE, Lawrence W. 1977. Black Culture and Black Consciousness. Afro-American Folk Thought from Slavery to Freedom. New York: Oxford University Press. MATTA, Roberto da. 1991. Carnivals, rogues and heroes: an interpretation of the Brazilian dilemma. Notre Dame, University of Notre Dame Press.

MAUSS, Marcel. 1970 [1923-1924]. The Gift. Forms and functions of exchange in archaic societies. London: Routledge \& Kegan Paul.

McCANN, Bryan. 2004. Hello, hello Brazil. Popular music in the making of modern Brazil. Durham: Duke University Press.

MIDDLETON, Richard. 1990. Studying Popular Music. Milton Keynes: Open University Press.

MIDDLETON, Richard. 200o. "Popular Music Analysis and Musicology: Bridging the Gap". In: R. Middleton (Ed.), Reading Pop. Approaches to Textual Analysis in Popular Music. Oxford: Oxford University Press, pp. 104-121. NADER, Laura. 1972. "Up the Anthropologist: Perspectives Gained from Studying Up”. In: HYMES, Dell (ed). Reinventing Anthropology. New York: Pantheon Books, pp. 284-311.

OGBURN, William F. 1964. “Southern Folkways Regarding Money”. In: On Culture and Social Change. Chicago, Chicago University Press, pp. 197-206. OLIVEN, Ruben George. 1984. "A Malandragem na Música Popular Brasileira”. Latin American Music Review 5(1): 66-96.

OLIVEN, Ruben George. 1988. "The Woman makes (and breaks) the Man: the Masculine Imagery in Brazilian Popular Music”. Latin American Music Review 9(1): 90-108.

OLIVEN, Ruben George. 1996. Tradition Matters. Modern gaúcho identity in Brazil. New York: Columbia University Press.

OLIVEN, Ruben George. 1998. "Looking at Money in America". Critique of Anthropology 18(1): 35-59.

OLIVEN, Ruben George. 1999. "Money in Brazilian Popular Music". Studies in 
Latin American Popular Culture 18: 115-137.

OLIVEN, Ruben George. 2009. "The Money Rhetoric in the United States”. In: S. Gudeman (ed.), Economic Persuasions (volume 3 of Studies in Rhetoric and Culture Series). New York \& Oxford: Berghahn, pp. 159-175.

OLIVEN, Ruben George. 2011. “The Imaginary of Brazilian Popular Music”.

Vibrant. Virtual Brazilian Anthropology 8(1): 170-207.

PEIRANO, Mariza. 1992. Antropologia no Plural. Três Experiências

Contemporâneas Brasília: Editora da Universidade de Brasília.

PEIRANO, Mariza. 2005. "A Guide to Anthropology in Brazil”. Vibrant. Virtual Brazilian Anthropology 2 (1/2): 54-87.

RUBIN, Rachel and MELNICK, Jeffrey. 2007. Immigration and American Popular Culture. New York: New York University Press.

SANDRONI, Carlos. 2001. Feitiço decente. Transformações do samba no Rio de Janeiro (1917-1933). Rio de Janeiro: Jorge Zahar Editor/ Editora da UFRJ.

TAGG, Philip. 200o. "Analysing Popular Music: Theory, Method, and

Practice”. In: R. MIDDLETON (ed.), Reading Pop. Approaches to Textual Analysis in Popular Music. Oxford: Oxford University Press, pp. 71-103. TATIT, Luiz. 2002. “Analysing popular song”. In: D. Hesmondhalgh \& K. Negus (eds.), Popular Music Studies. London: Arnold, pp. 33-50.

VELHO, Otávio. 2008. “A Antropologia e o Brasil, hoje”. Revista Brasileira de Ciências Sociais 23: 5-9.

VIANNA, Hermano. 1999. The Mistery of Samba. Popular music and national Identity in Brazil. Chapel Hill: University of North Carolina Press.

WEBER, Max. 1958. The Protestant Ethic and the Spirit of Capitalism. New York: Charles Scribner's Sons.

\section{About the author}

Ruben George Oliven is Professor of Anthropology at the Federal University of Rio Grande do Sul in Porto Alegre, Brazil and member of the Brazilian Academy of Sciences. He received his PhD from the University of London (London School of Economics and Political Science) and was a visiting professor at several universities, among them the University of California (Berkeley), Brown University, and the University of Paris. He was the President of the Brazilian Anthropological Association and of the Brazilian Association for Graduate Studies and Research in Social Sciences. He won the 
Erico Vannucci Mendes Prize for Distinguished Contribution to the Study of Brazilian Culture. His research interests include urbanization, national and regional identities, symbolic meanings of money, popular culture, and popular music. Email: ruben.oliven@gmail.com

Received February 4, 2012, approved June 1, 20121 